\title{
PERMANENT GRASSLAND RESTORATION TECHNIQUES - AN OVERVIEW
}

\author{
Wiesław Golka ${ }^{\mathrm{a}^{*}}$, Grzegorz Żurek ${ }^{\mathrm{b}}$, Jan Radosław Kamiński ${ }^{\mathrm{c}}$ \\ ${ }^{\text {a }}$ Institute of Technology and Life Sciences, Mazovian Research Centre in Kłudzienko \\ ${ }^{\mathrm{b}}$ Plant Breeding and Acclimatization Institute (IHAR) - National Research Institute \\ ${ }^{\text {c }}$ Department of Agricultural and Forest Machinery, Warsaw University of Life Sciences \\ *Corresponding author: e-mail: golkaw@o2.pl
}

\begin{tabular}{|c|c|}
\hline ARTICLE INFO & ABSTRACT \\
\hline $\begin{array}{l}\text { Article history: } \\
\text { Received: July } 2016 \\
\text { Received in the revised form: } \\
\text { September } 2016 \\
\text { Accepted: October } 2016 \\
\end{array}$ & \multirow{2}{*}{$\begin{array}{l}\text { Short review of grassland restoration techniques has been made with } \\
\text { emphasis on the application of newly developed wide-strip overseed- } \\
\text { ing aggregate. Machines currently available on the market are not } \\
\text { suitable for all types of soil and grassland conditions. Vredo seeder is } \\
\text { useless on muck soils, while Moore aggregate requires herbicide } \\
\text { application. Therefore it is not to be applied in organic farming. } \\
\text { Construction designated in ITP Kłudzienko (wide-strip overseeder) is } \\
\text { a very economical and effective, possible to be used also on muck } \\
\text { soils and without assistance of any chemicals. Operation of the ma- } \\
\text { chine consists of 'milling' of wide (about } 10 \mathrm{~cm} \text { ) strips of sod and } \\
\text { overseeding of mineral fertilizers and seeds of grasses, legumes and } \\
\text { herbs. Cultivator for soil 'milling' strips is driven by the tractor PTO. } \\
\text { By changing the spacing of strips, an oversown area can be resized } \\
\text { from } 20 \% \text { to } 40 \% \text {. The effect of overseeding, evaluated next year } \\
\text { exposed the increase of hay yield from } 0.8 \text { to } 1.2 \text { t ha }{ }^{-1} \text { of dry matter in } \\
\text { the first cut. Such innovative construction is particularly important in } \\
\text { dairy farms which are in the need of the best quality feed. }\end{array}$} \\
\hline $\begin{array}{l}\text { Key words: } \\
\text { grassland, } \\
\text { methods of renewal, } \\
\text { aggregate for overseeding }\end{array}$ & \\
\hline
\end{tabular}

\section{Introduction}

The Polish grasslands cover ca. $3.3 \cdot 10^{6}$ ha which represents $21.3 \%$ of the arable land in Poland (MSO, 2014). The grasslands (meadows and pastures) are important food source for cattle, and more recently, for sheep. Their most important function is the production of nutritious feed of optimal nutritional value and taste. The quality of feed and the performance and durability of grassland determine the profitability of the production of milk and beef. Grassland sward with appropriate species composition is very valuable feed even for high productive animals. Appropriate grassland management enables yield at the level of 10 $\mathrm{t}$ of hay per 1 ha. Currently estimated grassland yields in Poland are about $5 \mathrm{t} \cdot \mathrm{ha}^{-1}$ (Mendra et al., 2013). More than a half of permanent grassland suffers degradation. The first symptom of degradation is a reduction in yield and deterioration of their nutritional value. Yields from degraded grassland could be decreased below 70\% (Barszczewski et al., 2015). 
The need of periodic restoration of meadows and pastures results from the quantitative and qualitative changes in sward following the changing habitat conditions and climate, and also because of improper use (Kulik, 2010). In terms of definition, given by the Society of Ecological Restoration (SER), grassland restoration is 'the process of assisting the recovery of an ecosystem that has been degraded, damaged or destroyed. It is intentional activity that initiated or accelerates the recovery of an ecosystem with respect to its health, integrity and sustainability' (Gibson, 2009).

The following reasons which cause the grassland degradation were listed in the literature (Jankowska-Huflejt et al., 2005; Jankowska-Huflejt, 2007):

- improper mineral fertilizers - unfavorable ratio of ingredients, including $\mathrm{N}$ fertilization (resulting in excessive sward weeding with dangerous nitrophilous weeds as nettles and chickweed) and too low potassium fertilization on organic soil or even abandonment of this treatment;

- failure of treatments, especially rolling of post-bog grasslands, mainly in the early spring;

- improper application of liquid natural fertilizers (slurry and manure) which results in excessive growth of herbs and weeds that prefer high $\mathrm{N}$ and $\mathrm{P}$ concentration in soil as sorrel, common dandelion, thistle and others, especially from Apiaceae family;

- long-term excessive soil moisture (periodic floods) and the associated lack of oxygen in the root layer, which promotes the development of hydrophilic weeds (Juncus, horsetails, buttercups), sedges and tufted hair grass, while the disappearance of valuable grasses and legumes;

- long-term atmospheric drought in summer, often resulting in complete inhibition of growth of shallowly rooted grasses, allowing the development of the petal of herbs and deeply rooted weeds;

- errors during mowing (too low rotary mowing, not preferred by tall grasses) and hay collecting (destroying of sward by the wheels of heavy machinery);

- delayed harvest of the 1-st and 2-nd cuts, hay residues left on the meadow;

- pasture misuse, overgrazing, bad management practices i.e. excessive dents and damage to the sward, a large area of leavings and droppings, a large share of weeds, excessive and low biting of sward, grazing in conditions of excessive humidity;

- long-term, unilateral use of hay or grazing both on intensive and extensive meadows and pastures.

Rational technologies determining to a large extent quantity and quality of produced feed and the quality of the natural environment are key factors of the good exploitation of grasslands (Radkowski and Radkowska, 2014 a, b). Technological innovations, aimed at restoration and improvement of botanical composition, are particularly important in dairy and cattle meat farms, which are in the need of the best quality feed (Radkowska and Radkowski, 2015). The progressive degradation of grassland causes the decreased share of valuable species of forage grasses and legumes, and meadow sward, become loosened. Moreover, still very frequent firing of valuable grass species causes a decrease in the yield and reduces the quality of feed (Barszczewski and Paluch, 2005). Other problems are also not helpful as for example low efficiency of current grassland restoration practices in Poland and high share (more than 30\%) of habitats of bad water conditions i.e. post-bog soils, marsh-muck, often flooded and frequently dried mineral soils. These unfavorable condi- 
Permanent grassland...

tions may progress of grassland degradation as well as hinder the choice of the appropriate method of restoration.

\section{Restoration practices}

In Poland, following methods of restoration has been used so far:

1. Re-cultivation. This method has the following disadvantages: high labor and energy intensity of cultivation, grassland cannot be used after treatment for a certain time, high greenhouse gases emission (mostly $\mathrm{NO}_{2}$ and $\mathrm{CO}_{2}$ ) due to mineralization of soil organic matter during cultivation of use.

2. Fertilization with simultaneous rational use. Mostly used on frequently flooded and erosion threatened areas, where low productivity is the effect of nutrient deficiency (Medelete et al., 2015)

3. Direct overseeding. It involves introduction of valuable seeds of grasses and legumes on or into the meadow sward, thus complementing and enriching the species composition of permanent grasslands (Goliński, 1998; Huguenin Elie et al., 2006; JankowskaHuflejt, 2015; Jaurena et al., 2016). Compared with the re-cultivation, overseeding is much cheaper ( $40 \%$ less acc. to Baryła, 1996). Moreover, land can remain in use just after overseeding.

4. Selective herbicide application. This aims at elimination or significantly reduces an excessive share of undesired weeds, particularly those which may be hazardous to animals and those which are highly competitive with the valuable grass. Chemical control can be used in two periods: at spring and autumn. In conditions the sward was mowed or grazed, 3-4 weeks are necessary for sward to regrowth, but not higher than $20 \mathrm{~cm}$. Unfortunately selective herbicide protection is virtually ignored by growers. Most often this is due to concerns about the active substance residues in pasture sward and insufficient knowledge about the selective and safe use of herbicides on permanent grassland. What's more, over the past 5 years the range of selective and highly effective herbicides that can be applied in this method have been limited up to $80 \%$. Currently, growers have at their disposal only two selective herbicides: Starane 250 EC and Fernando Forte 300 EC (Badowski and Rola, 2003).

5. Total herbicide application followed by valuable grass seed sowing. This method is particularly recommended for grasslands that have been heavily infested by weeds (more than $60 \%$ coverage of the sward) or more than $20 \%$ of tufted hairgrass, wheat grass or rush (common or soft) in sward. In this method one active substance - glyphosate is mostly used, which allows the complete elimination of undesired weeds together with the "old" sward. In wet habitats on peat-muck soils, sowing of valuable grass seed should be made in September and on mineral soils to the first decade of October. Immediately after sowing a rolling with plain meadowland shaft should be performed once. When the sward reaches a height of $10 \mathrm{~cm}$, it must be cut off to about $6 \mathrm{~cm}$, and cuttings should be left on the field (Badowski and Sekutowski, 2007).

Currently, the most commonly used method of permanent grassland restoration is direct overseeding. It is successful if (Barszczewski et al., 2015):

- the competitiveness of old sward is limited, 
- soil moisture is optimal for the development of new seedlings,

- proper plant species were selected,

- optimal soil pH is ensured,

- fertilization is adequate with limited nitrogen.

Implementation technique is also important for overseeding. A common way is to introduce seeds into the soil with a different seeding sections, for example disc, drill or knife with combination of a relevant sward preparation and management after seeding. The goal is to perform all restoration procedures during a single pass of overseeding unit. This gives measurable economic effects resulting from fewer trips across the field: fuel efficiency and less labor (Golka and Ptaszyński, 2008; Hermenean and Mocanu, 2009).

For direct overseeding in Poland the most popular aggregates are: Vredo, Kockerling Herbamat and Moore where the narrow slit sowing technology is used. It should be mentioned that Kockerling aggregate with a knife sward cutting systems were completely useless on muck soil, due to difficulties in sward cutting and sward pieces tearing (Łyszczarz, 2010).

Vredo seeder is equipped with two cutting discs in the shape of a ' $\mathrm{V}$ ' to make a narrow slit in a grassland sward.

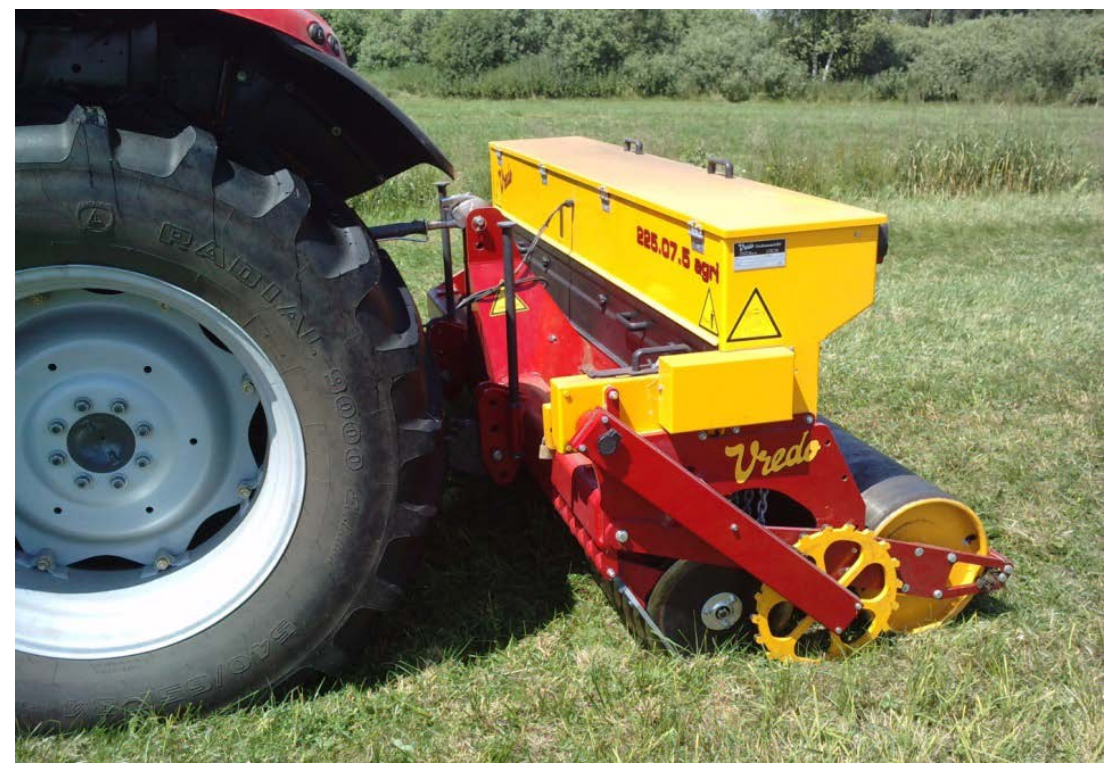

Figure. 1. Vredo overseeding aggregate (source: Vredo catalogue)

The angle between cutting discs control proper sward cutting angle. The seed is properly guided between the V-shaped discs and dispended into the slit at the correct, adjustable depth $(1-2 \mathrm{~cm})$. All elements are separately suspended, therefore always working at the same depth. Vredo sowing elements can deflect up to $15 \mathrm{~cm}$. Thus, they can work on uneven ground, keeping similar sowing depth. Slits in a sward are closing with a following packer roller. The weight of a packer roller is different due to different soil types. It is regu- 
Permanent grassland...

lated by different amounts of water added into the packer roller. Similar to Kockerling aggregate it is not applicable on muck soils.

Different systems of sward cutting and seed placing in soil were used in Moore overseeding aggregate. It is equipped with cutting discs with a seed sowing system, cast iron packing wheels and rubber support wheels. The slit in a sward is first made by cutting disc and further widen by special wedge adjacent to the cutting wheel. In such a slit of ca. $4 \mathrm{~cm}$ seeds are placed trough seed pipes installed just behind the wedge. Slits are closed by packing wheels. Sowing devices receive the drive from the driving wheel, not from the driving shaft (not installed).

Overseeding with the slit technique requires chemicals application that reduces old sward. Therefore, it is not possible to be used in organic farming. Following disadvantages has been defined for slit overseeding:

- it is necessary to apply chemicals against plants from old sward that can overgrow new seedlings;

- it is not effective on muck soils, due to problems with sward cutting.

Keeping all above in mind, activities were undertaken in IBMER (since 2010 ITP) to design aggregate for direct wide-strip grassland overseeding to eliminate all the mentioned disadvantages.

\section{Grassland renovation with wide-strip overseeding aggregate}

In 2005 research were undertaken on the prototype of a wide-strip aggregate made in State Machinery Station (POM) in Brodnica due to documentation prepared by IBMER. The results of the research prove the compatibility of quality indicators of cultivation and sowing, as well as indicators of inequality of cultivation depth, thickness of a tilled layer and fragmentation required with the agro technical recommendation for seedbed soil (Ptaszyński, 2005). Sowing and fertilizing quality recommendations were also met. Research was undertaken in 3 dairy farms. With the mentioned prototype, field expositions were also made in regions of operation of agricultural extension centers in Minikowo, Stare Pole and Szepietowo. Comparisons were also made for grass emergence with Vredo and Moore aggregates. The effects of overseeding using wide strips were much more favorable. The test results were used to improve the mentioned prototype. Unfortunately, series production of mentioned aggregate has not been launched. Therefore the dissemination of new technology was prevented. After years of research, tests and modifications made by IBMER and further by ITP, the aggregate is still in the implementation phase to serial production. In 2016, ITP again attempted to start serial production and signed deployment agreement with one of the domestic factories. Research conducted in the recent years indicates a full suitability of the mentioned aggregate for commissioning in the meadows and pastures of family farms, including organic farming.

The wide-strip aggregate was designated to renovate destroyed meadows and pastures as well as to enrich existing sward with valuable plant species without interrupting their use. Operation of the machine consists of 'milling' wide (about $10 \mathrm{~cm}$ ) strips of sod and overseeding of mineral fertilizers and seeds of grasses, legumes and herbs. A cultivator for soil 'milling' strips is driven by the tractor PTO. By changing the spacing of strips the oversown area can be can resized from $20 \%$ to $40 \%$. The effect of overseeding, evaluated 
next years after the seeding year exposed the increase of hay yield from 0.8 to $1.2 \mathrm{t} \cdot \mathrm{ha}^{-1}$ of dry matter in the first cut. The share of perennial ryegrass, meadow fescue, timothy grass and red clover also increased in grassland sward.

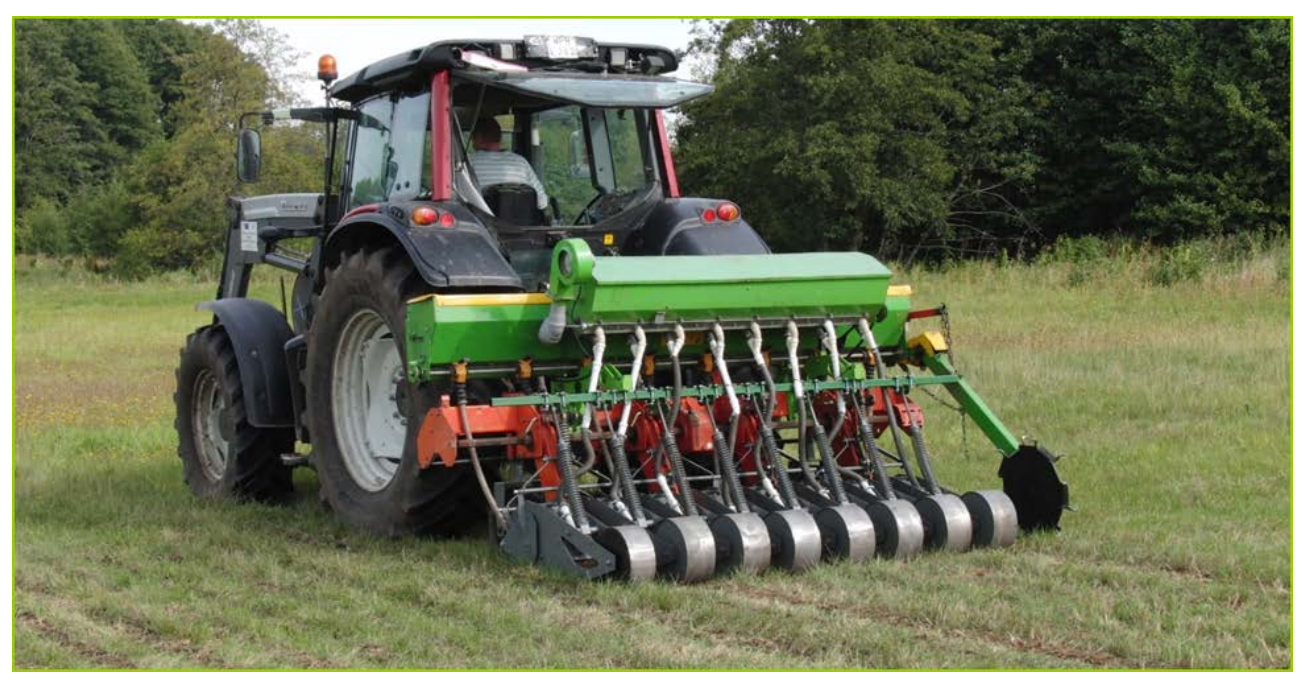

Figure 2. Wide-strip overseeding aggregate for grassland renovation (source: MAZOBITP, Kłudzienko)

Table 1.

Financial expenditures incurred for sward renovation with wide-strip overseeding aggregate

\begin{tabular}{|c|c|c|c|c|}
\hline $\begin{array}{l}\text { Specification } \\
\text { per 1ha }\end{array}$ & $\begin{array}{c}\text { Units } \\
\text { loose sward }\end{array}$ & $\begin{array}{c}\text { Light soil } \\
\text { loose sward }\end{array}$ & $\begin{array}{c}\text { Medium soil } \\
\text { compact sward }\end{array}$ & $\begin{array}{l}\text { Organic } \\
\text { oil }\end{array}$ \\
\hline Fuel & (liters) & $7-9$ & $13-16$ & $9-13$ \\
\hline Working time & (hours) & 1,25 & 2,5 & 2,4 \\
\hline Machine costs & $(\mathrm{PLN})$ & 87 & 174 & 167 \\
\hline
\end{tabular}

\section{Conclusion}

As it has been shown in the above review of the grassland restoration techniques it is worthwhile to launch in Poland an aggregate to wide-strip overseeding. The results of the research conducted so far indicate the usefulness of such a construction for overseeding of meadows both on muck as well as mineral soils. Therefore there is a possibility of replacing on the domestic market few imported aggregates with more comprehensive own aggregate.

Grassland overseeding with the mentioned specialized and innovative unit is a very economical and effective method. Our study has also shown its suitability for application on muck soils, which cannot be done with previously listed imported units.

Moreover, overseeding completely eliminates the need for herbicide sprays to inhibit the growth of the old sward. In addition, it stimulates the growth of seedlings due to local 56 
Permanent grassland...

fertilization. As a result, this method can be used also on organic grassland farms. Aggregates produced in Poland will be also cheaper than imported machinery.

In the years 2012-2015, the Centre of ITP in Kłudzienko continued to improve the construction of aggregate, including research conducted on Biebrza meadows on muck and mineral soils.

Promotional activities were also carried out, organized jointly with the Agricultural Advisory Centres (Radom, Mazovia, Modliszewice, Kłudzienko), field expositions of the aggregate for farmers and expositions during AGROTECH Fairs in Kielce. In Kłudzienko videos presenting the aggregate 'in-action' were also made for farmers, agricultural advisory staff and teachers of agricultural schools. Discussions with farmers during the shows identified the need to launch grassland restoration services.

Whereas the frequency of the meadows overseeding by farmers (every 4-5 years), aggregates should be purchased and used mainly by individuals or firms providing services to farmers (within the village or commune). In Poland there is ca. 1560 typically rural municipalities. Assuming that each of these municipalities will create service center for grassland restoration, the demand in the domestic market for such units is approx. 1200-1300 units. Annual market demand can be estimated at 20-60 units. In the first 3 years after the start of production to about 100 pcs per year after a proper marketing campaign. If the profitability of milk production will remain at current levels, the annual demand may be even greater.

\section{References}

Badowski, M., Rola, H. (2003). Ocena przydatności herbicydu Fernando 225 EC do zwalczania Rumex crispus i Urtica dioica na użytkach zielonych. Postępy w Ochronie Roślin, 43(2), 521-523.

Badowski, M., Sekutowski, T. (2007). Chemiczna renowacja zaniedbanych trwałych użytków zielonych. Inżynieria Rolnicza, 3(91), 11-17.

Barszczewski, J., Jankowska-Huflejt, H. Mendra, M. (2015). Renowacja trwałych użytków zielonych. Materiały informacyjne $n r$ 42. ITP Falenty, 20.

Barszczewski, J., Paluch, M. (2005). Wybrane problemy zrównoważonego gospodarowania związane z produkcją pasz na użytkach zielonych. Wieś Jutra,3(80), 33-34.

Baryła, R. (1996). Renowacja trwałych łąk i pastwisk w siedliskach grądowych ze szczególnym uwzględnieniem podsiewu, Zeszyty Problemowe Postępów Nauk Rolniczych, 442, 23-30.

Gibson, D.J. (2009). Grasses and Grassland Ecology, Oxford University Press, New York, 305.

Goliński, P. (1998). Nowoczesne sposoby podsiewu użytków zielonych. Eąkarstwo w Polsce, 1, 17-29.

Golka, W., Ptaszyński, S. (2008). Opracowanie rozwiązań technicznych i organizacyjnoekonomicznych dla rolnictwa ekologicznego. IBMER, Warszawa, 25.

Hermenean, I., Mocanu, V. (2009). New mechanization alternatives with low inputs for over sowing degraded grasslands. Research Journal of Agricultural Science, 41(2), 423-437.

Huguenin-Elie, O., Gago, R., Stutz, C., Lüscher, A., Kessler, W. (2006) Long-term effects of fertilization on herbage composition yield and quality of an Arrehenatherion - type meadow. Grasslands Science in Europe, 11, 550-553.

Jankowska-Huflejt, H., Wróbel, B., Gutkowska, A., Burs, W. (2005). Czynniki kształtujące trwałość użytków zielonych. Wiadomości Melioracyjne i Łąarskie, 4, 197-202.

Jankowska-Huflejt, H. (2007). Rolno-środowiskowe znaczenie trwałych użytków zielonych. Problemy Inżynierii Rolniczej, 1(55), 23-34. 
Jankowska-Huflejt, H. (2015). Wiosenny podsiew łąk i pastwisk. Portal Agrotechnika. Acquired from http://agro-technika/archiwa/wiosennypodsiew-łak-i- pastwisk.pl

Jaurena, M., Lezama, F., Salvo, L., Cardozo ,G., Ayala, W., Terra, J., Nabinger, C. (2016). The Dilemma of Improving Native Grasslands by Overseeding. Rangeland Ecology \& Management, 69(1), 35-42.

Kulik, M. (2010).Wpływ technologii regeneracji runi łąkowej na zmiany jej składu gatunkowego. Annales UMCS, Sectio E, 65(4), 94-104.

Łyszczarz, R., Dembek, R., Suś, R., Zimmer-Grajewska, M., Kornacki, P. (2010) Renowacja łąk trwałych położonych na glebach torfowo-murszowych. Woda-Środowisko-Obszary Wiejskie, 10(4), 129-148.

Medelete, D. M., Panzaru, R. L. (2015). Economic efficiency on overseeding grasslands from Preajba - Gorj county in 2014. Acta Universitatis Civiniensis, 67(1), 123-125.

Mendra, M., Barszczewski, J. (2013). Zastosowanie podsiewów w renowacji użytków zielonych. Hodowca Bydla, 3, 36-38.

Ptaszyński, S. (2005). Założenia do budowy siewnika do podsiewu łąk i pastwisk. IBMER, Warszawa, 21.

Radkowski, A., Radkowska, I. (2014 a). Ocena jakości i wartości pokarmowej kiszonek z runi łąkowej wybranych gospodarstw Polski południowo-wschodniej. Wiadomości Zootechniczne, R. LII, 1, 32-37.

Radkowski, A., Radkowska, I. (2014 b). Wartość pokarmowa kiszonek sporządzanych z runi łąkowej o zróżnicowanym udziale koniczyny łąkowej oraz wpływ ich skarmiania na przyrosty masy ciała buhajków i jałówek rasy Limousine. Roczniki Naukowe Zootechniki, 41(2), 129-137.

Radkowski, A., Radkowska, I. (2015). Przyrosty masy ciała bydła mięsnego rasy Limousine w zależności od udziału koniczyny białej (Trifolium repens L.) w runi pastwiskowej. Wiadomości Zootechniczne, R. LIII, 4, 3-9.

\section{TECHNIKI RENOWACJI TRWAŁYCH UŻYTKÓW ZIELONYCH}

Streszczenie. Zaprezentowano krótki przegląd technik renowacji użytków zielonych ze szczególnym uwzględnieniem nowego agregatu do szeroko pasowego podsiewu. Istniejące obecnie na rynku urządzenia do renowacji użytków zielonych nie sa dostosowane do wszystkich typów gleby i stanowisk łąkowych. Siewnik firmy Vredo jest bezużyteczny na glebach murszowych, podczas gdy agregat firmy Moore wymaga aplikacji herbicydu, co wyłącza jego przydatność w gospodarstwach ekologicznych. Alternatywna konstrukcja zaprojektowana w ITP Kłudzienko (agregat do podsiewu szeroko pasmowego) jest urządzeniem efektywnym i ekonomicznym, do zastosowania również na glebach murszowych i niewymagającym posiewnej aplikacji herbicydu. Działanie maszyny polega na frezowaniu szerokich $(0 \mathrm{k} .10 \mathrm{~cm})$ pasów darni i podsiewie nawozów mineralnych, nasion roślin motylkowych, traw i ziół. Glebogryzarka pasowa napędzana jest od WOM ciągnika. Poprzez zmianę rozstawu podsiewanych rzędów może być zmieniany udział podsianej powierzchni w granicach $20-40 \%$. Skutki podsiewu, oceniane od pierwszego pokosu w roku następnym po podsiewie, wykazywały wzrost plonów siana o 0,8-1,2 ton s. m. w pierwszym pokosie. Tego typu innowacyjna konstrukcja jest szczególnie przydatna w fermach krów mlecznych, gdzie niezbędna jest najwyższa jakość paszy.

Słowa kluczowe: użytki zielone, agregaty, metody renowacji, podsiew 